\title{
TRADISI TAMA LAMONG DALAM UPACARA KHITANAN PADA MASYARAKAT SUMBAWA DI DESA RHEE KECAMATAN RHEE KABUPATEN SUMBAWA
}

\author{
Zakaria Anshori M.Hum \\ (Dosen Perserikatan Muhammadiyah Mataram)
}

\section{INFO ARTIKEL}

Riwayat Artikel:

Diterima: 10-09-2016

Disetujui: $30-09-2016$

\section{Kata Kunci:}

Tradisi, Tama Lamong.

\begin{abstract}
Abstrak: Kebudayaanbbangsa Indonesia telah tumbuh dan berkembang sejak ribuan tahun yang lalu dan telah mengalami akulturasi dengan budaya asing. Namun kemudian tidak dapat dipungkiri adanya sebagian kebudayaan yang lampau masih mewarnai kehidupan bangsa Indonesia dimasa kini. Demikian pula halnya dengan tradisi Tama Lamong dalam upacara khitanan adat Sumbawa merupakan bagian dari bangsa Indonesia yang sudah ada sejak dahulu sebagai budaya spiritual. Dalam hal ini kebudayaan Indonesia yang tumbuh dan berkembang telah menunjukkan suatu indentitas tersendiri bagi bangsa Indonesia yang telah membedakan dengan bangsa-bangsa didunia dan ikut mewarnai system nilai dan kehidupan. Di antar aunsur-unsur yang dapat membentuk kepribadian bangsa yang merupakan bagian dari kebudayaan bangsa Indonesia diantaranya adalah nilai-nilai budaya local seperti yang terkandung dalam Tradisi Tama Lamong Dalam Upacara Khitanan Pada Masyarakat Bangsawan Sumbawa di Desa Rhee Kecamatan Rhee Kabupaten Sumbawa sebagai budaya spiritual dan wujud ketaatan mereka terhadap apa yang merekayakini.

Penelitian yang digunakan adalah melalui pendekatan kualitatif dengan metode fenomenologi budaya. Lokasi penelitian ini adalah di Desa Rhee Kecamatan Rhee Kabupaten Sumbawa. Pemilih aninfor Mandan responden penelitian dilakukan secara purposive. Tehnik pengumpulan data yang digunakan adalah teknik observasi, wawacara dan dokumentasi. Data yang terkumpul dianalisis secara interakif dan berlangsung melalui langkah redukasi data, peyajian data danverifikasi (kesimpulan).

Adat- istiadat serta kebudayaan seperti Tradisi Tama Lamong dalam upacara Khitanan masyarakat Sumbawa masih berkembang dan masih dilestarikan, karena adat dan kebudayaaan tersebut sudah melekat dalam diri masyarakat desa Rhee dan sudah menjadi keyakinan dan kepercayaan turun-temurun dari leluhur atau nenek moyang mereka. Selain itu tradisi Tama Lamong juga terbentuk disertai dengan makna dan fungsi bagi warga masyarakat baik secara individu maupun sebagai kelompok sosial. Tradisi Tama Lamong ini tidak meyimpang dari aturan atau norma yang ada dalam masyarakat dan patut dijaga serta dipelihara, adapun makna dan nilai yang dapat dijumpai dalam tradisi Tama Lamong tersebut nilai sosial, nilaiseni, dan nilai religi.
\end{abstract}

ABSTRAK

\section{A. LATAR BELAKANG}

Budaya adalah suatu cara hidup yang berkembang dan dimiliki bersama oleh sebuah kelompok orang dilakukan secara turun temurun. Budaya terbentuk dari berbagai unsur-unsur yang rumit, termasuk sistem agama dan politik, adat istiadat, bahasa, pakaian, bangunan, dan karya seni. Bahasa, sebagaimana juga budaya, merupakan bagian yang tidak terpisahkan dari diri manusia sehingga banyak orang cenderung menganggapnya diwariskan secara genetis. Ketika seseorang berusaha berkomunikasi dengan orang-orang yang berbeda budayamaka dapat dilihat secara jelas akan perbedaannya. Hal ini membuktikan bahwa budaya itu dapat dipahamidandipelajari.

Pulau Sumbawa merupakan daerah yang banyak menyimpan beragam budaya dankaya akan nilai-nilai tradisinya. Beragam tradisi adat yang mewarnai kehidupan masyarakat suku Sumbawa (tau samawa) di Kabupaten Sumbawa sampai sekarang masih banyak dijumpai dan tetap dipertahankan kelestariannya.Salah satu kepercayaan tersebut adalah kepercayaan Tama Lamong.

Tau Samawa adalah sebutan khusus untuk masyarakat Suku Sumbawa, yang mendiami bagian barat Pulau Sumbawa atau bekas wilayah Kesultanan Sumbawa, dengan luas wilayah $8.493 \mathrm{~km}^{2}$ (lebih dari setengah Pulau Sumbawa dengan luas keseluruhan mencapai $14.415,45 \mathrm{~km}^{2}$ ). Sebagian besar wilayahnya terdiri atas perbukitan dan pegunungan dengan puncak tertinggi 1.730 meter diatas dipermukaan air, yaitu berada di Gunung Batu Lanteh. Gunung ini berdiri tegak di antara lima pegunungan lainnya, berada di bagian tengah dan selatan pulau. Mengarah ke gunung ini terdapat sebuah sungai terbesar 
bernama Brang Beh, yang juga mengalir menuju Teluk Lampui dan menuju daerah-daerah di sekitar pegunungan lainnya, kemudian bertemu dengan anak-anak sungai lainnya yang lebih kecil.

Sebagian besarTau Samawa tersebar mulai wilayah Kecamatan Empang di ujung timur hingga Kecamatan Alas di ujung barat. Batas teritorial kedua daerah kabupaten ini adalah sebelah utara berbatasan dengan Laut Flores, sebelah selatan dengan Samudera Indonesia, sebelah barat dengan Poto Tano, dan sebelah timur berbatasan dengan Kabupaten Dompu. Jumlah populasi suku Sumbawa sekarang diperkirakan lebih dari 500.00o jiwa.

Suku Sumbawa yang terus berkembang saat ini merupakan campuran antara keturunan etnik-etnik pendatang atau dari pulau-pulau lain yang telah lama menetap dan mampu beradaptasi dengan lingkungan barunya, serta sanggup berakulturasi dengan para pendatang lain yang masih membawa identitas budaya nenek moyang mereka, baik yang datang sebelum maupun pasca meletusnya Gunung Tambora tahun 1815. Para pendatang ini terdiri atas etnik Jawa, Madura, Bali, Sasak, Bima, Sulawesi (Bugis, Makassar, Mandar), Sumatera (Padang dan Palembang), Kalimantan (Banjarmasin), dan Cina (Tolkin dan Tartar), serta Arab yang rata-rata mendiami dataran rendah dan pesisir pantai pulau ini, sedangkan sebagian penduduk yang mengklaim diri sebagai pribumi atau tau samawatotok menempati wilayah pegunungan seperti Tepal, Dodo, dan Labangkar akibat daerah-daerah pesisir dan dataran rendah yang dulunya menjadi daerah pemukiman mereka tidak dapat ditempati lagi pasca bencana alam Tambora yang menewaskan hampir dua pertiga penduduk Sumbawa kala itu.

Sistem kekerabatan dan keturunan Tau Samawa pada umumnya bilateral, yaitu sistem penarikan garis keturunan berdasarkan garis silsilah nenek moyang laki-laki dan perempuan secara bersamaan. Dalam sistem kekerabatan ini, baik kerabat pihak ayah mapun pihak ibu diklasifikasikan menjadi satu dengan istilah yang sama, misalnya untuk saudara tua ayah atau ibu, dan untuk saudara yang lebih muda dari ayah atau ibu. Kelompok keluarga yang lebih luas yaitu pata, pata yaitu kerabat dari laki-laki atau wanita yang ditarik dari kakek atau nenek moyang sampai derajat keenam, sehingga dalam masyarakat Sumbawa dikenal sepupu satu, sepupu dua sampai sepupu enam.

Pada kehidupan masyarakat Sumbawa tradisional, beberapa keluarga inti dapat tinggal dalam satu rumah panggung, yaitu rumah yang didirikan di atas tiang kayu yang tingginya berkisar antara 1,5 hingga 2 meter dengan tipologi persegi panjang, atapnya berbentuk seperti perahu yang terbuat dari santek atau bambu yang dipotongpotong (kini banyak diganti dengan genting). Pada bagian depan atau belakang, bagian belakang dipasang anak tangga dalam hitungan ganjil antara 7 , 9, 11 bergantung keperluannya. Adapun tata ruang bagian dalam umumnya merupakan perpaduan antara bentuk rumah adat Bugis-Makassar yang dikombinasi dengan arsitektur rumah orang Melayu. Untuk rumah-rumah panggung di pedesaan lebih disukai menghadap ke timur atau matahari terbit yang melambangkan kekuatan, ketabahan, dan harapan limpahan rezeki.

\section{B. METODE PENELITIAN}

\section{Metode yang digunakan}

Metode Penelitian ini menggunakan metode penelitian kualitatif dengan pendekatan fenomenologi budaya. Istilah fenomenologi sering digunakan sebagai angggapan umum untuk menunjukkan pada pengalaman subjektif dari berbagai jenis dan tipe subjek yang ditemui. Fenomenologi kadanag-kadang digunakan sebagai perspektif filosofi dan juga digunakan sebagai pendekatan dalam metodelogi kualitatif.Dalam pandangan fenomenologi berusaha memahami arti pristiwa dan kaitan-kaitannya terhadap orang yang berada dalam situasi-situasi tertentu (Moleong,2012:15). Jadi Penelitian Fenomenologi budaya merupakan penelitian untuk memahami, menggali, dan menafsirkan arti dan pristiwa-pristiwa, fenomena (gejala-gejala sosial yang alamiah) dan hubungan dengan orang-orang yang biasa dalam situasi tertentu atau berusaha memahami makna dari suatu pristiwa atau fenomena yang saling berpengaruh dengan manusia dalam situasi tertentu.

\section{Subyek Penelitian}

Adapun Subjek penelitian ini adalah tokoh adat, tokoh agama, dan tokoh masyarakat pada umumnya,

\section{Tehnik Pengumpulan Data}

Tekhnik yang digunakan dalam pengumpulan didalam penelitian ini adalah:
a. Observasi
b. Wawancara
c. Dokumentasi

\section{Teknik Analisis Data} kualitatif yaitu:

Ada tiga (3) tahapan dalam menganalisis data

a. Reduksi Data

b. Penyajian Data

c. Verifikasi

\section{HASIL DAN PEMBAHASAN}

\section{Hasil Penelitian}

\section{a. Proses Pelaksanaan Tradisi Tama Lamong}

Dalam suatu budaya tidak akan terlepas dari adanya suatu tradisi dan kebiasaan yang khas, sehingga mencerminkan daerah atau suatu tempat tertentu. Tradisi tama lamong ini memiliki alur yang cukup panjang, hal ini dikarenakan adanya berbagai macam berlengkapan dan persiapapan yamg harus disiapkan sebelum tradisi tama lamong dimulai. Adapun alur pelaksanaan tradisi tama lamongsebagai berikut ini:

\section{1) Persiapan tama lamong}

Sebelum pelaksanaan tama lamong terlebih dahulu melakukan persiapan. Dalam persiapan ini perlu dipersiapkan segala peralatan dan perlengkapan tardisi. Adapun perlengkapan yang disediakan dalam tradisi tama lamong, mengandung makna dan fungsi sebagai berikut:

a) $A i$ (air) bermakna kesucian

b) Lilin bermakna penerangan

c) Loto kuneng (beras kuning) bermakna spiritualitas 
d) Nyir (kelapa) bermakna pengobatan

e) Dila malam bermakna penerang

f) Dulang (nampan) bermkna sosial

g) Kre putih (kain putih) bermakna kesucian

h) Lamong pene bermakna kehormatan

i) Kawari bermakna kehormatan

j) Mayang bermakna pengobatan dan kecantikan

k) Pancar bermakna bermakna kecantikan

l) Bore (hiasan dahi) bermakna kedewasaan

m) Godong puntikbermakna spiritualitas

n) Sedangkan kegunaan dan fungsi yang terdapat dalam perlengkapan Tama Lamong adalah sebagai berikut ini:

o) $A i$ (air) digunakan untuk membasuh,setelah itu dipercikan ke seluruh tubuh si anak perempuan.

p) Lilindigunakan sebagai penerang

q) Loto kuneng (beras kuning) digunakan denan cara menaburkannya keseluruh tubuh si anak.

r) Nyir (kelapa), airnya digunakan untukmembasuh tubuh si anak dan untuk minum. Dila malam sebagai penerang

s) Dulang (nampan) digunakan untuk meletakan semua perlengkapan yang diperlukan.

t) Kre putih (kain putih) dipakaikan oleh si anak.

u) Lamong pene dipakaikan kepada si anak hingga sebanyak 7 kali dengan 7 warna baju yyang berbeda-beda.

v) Kawari dikalungkan dileher si anak

w) Mayang dipakai untuk memercikan air ketubuh si anak

x) Pancardigunakan ditangan si anak perempuan.

y) Bore (hiasan dahi) digunakan sebagai hiasan di dahi anak perempuan.

z) Godong puntik digunakan untuk meletakan bahan-bahan yang dipakaidalam upacara Tama Lamong.

Setelah peralatan dan perlengkapan dalam tradisi tama lamong ini sudah lengkap. Maka orang tua si anak perempuan yang akan melaksanakan tradisi tersebut langsung menghubungi sandro (dukun) yang biasa melaksanakan tradisi tama lamong tersebut. Sandro (dukun) memiliki karakteristik yaitu sangat paham tentang seluk-beluk dalam pelaksanaan tradisi tama lamong, tidak hanya paham dalam tama lamong saja melainkan tentang upacara basunat (khitan) setelah semua dianggap selesai, maka tradisi tama lamong yang dirangkaikan dengan basunat ini akhirnya dilaksanakan. Seperti yang diungkapkan oleh bapak H. Jabar tentang persiapan tama lamong ini sebagai berikut:

"persiapan tama lamong ini harus benar-benar matang dan segala perlengkapan juga harus tersedia semuanya. Apabila diantara salah satu perlengkapan dari tama lamong ini tidak tersedia serta tidak matang dalam persiapannya maka akan berdampak buruk pada si anak nantinya. Maka untuk menghindari hal-hal yang buruk orang tua anak tersebut mempersiapkan semua perlengkapan tersebut jauh hari sebelum acara pelaksanakan tama lamong dimulai (H. Jabar 26 Oktober 2015)"

\section{2) pelaksanaan tama lamong}

Tradisi tama lamong ini dilaksanakan pada malam hari atau pagi hari tergantung dari orang tua yang mempunyai hajatan. Dalam pelaksanaan ini dihadiri oleh para tokoh masyarakat dan tokoh adat masyarakat Desa Rhee dan banyak dihadiri oleh warga yang ada di Desa Rhee maupun yang berasal dari luar Desa Rhee. Adapun alur pelaksaaan tradisi tama lamong sebagai berikut :

a) Pemandian anak

Tahap awal didalam pelaksanaan tradisi tama lamong ini adalah pemandian anak yang akan melakukan tradisi tama lamong, waktu pelaksanaan mandi ini tergantung dari waktu pelaksanaan upacaranya. Jika tradisi tama lamong dilaksanakan pada malam hari, maka pemandian dilakukan menjelang magrib, jika tradisinya dilaksanakan pada hari biasa, maka pemandian dilakukan pagi hari setelah sholat subuh dan menjelang terbitnya matahari. Pada proses pemandian ini dilakukan oleh seorang sandro (dukun). Air yang akan digunakan mandi oleh si anak sebelumnya sudah diberi do'a khusus oleh sandro (dukun).

b) Pemakain perlengkapan tama lamong

Setelah proses pemandian selesai, kemudian dilanjutkan dengan pemakaian perlengkapan tama lamong seperti lamong pene, 7 warna, kawari dan kre putih. Baju yang dipakaikan ada 7 warna yang berbeda, pemakaian perlengkapan ini dilakukan oleh 7 orang sandro (dukun) yang secara bergilir mengenakan ketujuh baju tersebut. Setelah itu baru diberi pancar, bore, dan loto kuneng. Setelah semuanya selesai maka proses upacara khitan langsung dimulai.

c) Pengiringan oleh sakeco dan do'a

Selama pelaksanaan mengenakan perlengkapan tama lamong ini selalu diiringi oleh musik sakeco yang berupa memainkan rabana dan gendang. Didalam iringan ini diiringi pula oleh doa-doa dari para tokohtokoh agama yang ada di Desa Rhee, dalam pengiringan ini mengunakan alat-alat pengeras suara sehingga suara dari orang-orang basakeco terdengar hingga seluruh pelosok Desa Rhee. Sakeco sendiri merupakan salah satu musik khas Sumbawa yang selalu ditampilkan dalam berbagai acara di sumbawa termasuk dalam acara adat tama lamong. Pengiringan oleh musik sakeco ini dilakukan secara beramai-ramai hingga proses tama lamong berahir. Adapun hasil wawancara bersama bapak supriadi tentang pengiringan musik sakeco dalam pelaksanaan tama lamong yaitu sebagai berikut :

"dalam setiap acara khitan khususnya dalam acara tama lamong, selalu ada musik pengiring sakeco oleh 4 orang pemain. Dalam mengiring acara tama lamong ini para orang basakeco ini saling sahut-sahutan satu sama lainnya. Isi sakeco yang dibawakan berisikan doa-doa buat si anak yang sedang melaksanakan tradisi tama lamong (supriadi, 28 juli 2015)

d) Pelaksanaan basunat (khitan)

Basunat ini tidak lain adalah sunat yang diajarkan oleh agama islam sebagai salah satu kewajiban umat muslim ketika sudah balig. Dalam adat Sumbawa basunat ini merupakan sebuah tradisi atau kebiasaan, seperti didaerah-daerah lainnya seperti jawa, sumatra dan daerah lainnya. Walupun basunat ini merupakan kewajiban setiap umat muslin disetiap daerah, akan tetapi dalam pelaksanaan atau tata cara merayakannya berbeda-beda seperti dalam adat jawa orang yang mengadakan sunatan, akan melakukan 
perayaan yaitu Mbarang Gawe selama tiga hari tiga malam dan dalam adat Sumbawa basunat ini dilakukan melalui beberapa tahapan atau langkah yang selanjutnya dirangkaikan dengan tradisi tama lamong, yaitu sebagai berikut:

1. Pemandikan air suci dipagi hari

2. Mengenakan perlengkapan basunat seperti lamong pene, kawari, kre puti

3. Tradisi tama lamong

4. Basunat (khitan)

Dalam pelaksanaan basunat ini si anak perempuan didampingi oleh kedua orang tuanya beserta sanak saudaranya. Dalam adat Sumbawa basunat ini biasanya dilaksanakan dengan meriah dan berbagai hidangan atau makanan yang disajikan untuk para tamu baik undangan maupun tamu sekitarnya yang datang. Karena hal ini merupakan suatu tradisi dan ciri khas suatu daerah maka masyarakat Desa Rhee melestarikan tradisi tersebut agar tidak punah karena perkembangan zaman.

\section{3) Penutup acara tradisi tama lamong}

Setelah pelaksanaan tama lamong dan khitan selesai, maka pada acara penutup ini dilakukan dengan membagi jajan yang sudah dibungkus oleh pihak keluarga penyelenggaran acara. Selain itu juga semua masyarakat yang datang ke acara tersebut disuguhi makanan. Selain masyarakat Desa Rhee, banyak juga masyarakat dari Desa lainnya yang datang untuk memberikan sumbangan kepada anak yang dikhitan tersebut. Dalam pemberian uang ini bisa secara langsung dan bisa juga dimasukkan ke dalam amplop, selanjutnya uang tersebut diganti dengan makanan seperti kue dan nasi yang telah dipersiapkan sebelumnya. Ahirnya melalui penutupan acara tradisi tama lamong yang disatukan dengan acara khitan ini selesai dengan diakhiri dengan jabat tangan antara keluarga penyelenggara hajatan dengan masyarakat yang datang.

Itulah alur dalam pelaksanaan tradisi tama lamong yang dirangkaikan dengan upacara khitan (basunat) adapun hasil wawancara bersama ibu fatimah menjelaskan tentang tata cara tradisi tama lamong

"pelaksanaan tama lamong dilaksanakan oleh anak perempuan yang akan dikhitan, terlebih dahulu melakukan tradisi tama lamong. Adapun proses acaranya yaitu anak perempuan terlebih dahulu disiram mengunakan air kelapa, mayang (bunga kelapa)dan mengambil pancar diletekan diatas telapak tangan si anak, lalu bore diletakan diatas kening dan kemudian diambil 7 buah baju yang disebut lamung pene (baju pendek)yang memiliki 7 warna yang berbeda. Baju tersebut dipakaikan oleh 7 tokoh adat dan ketujuh orang tersebut menyiram si anak mengunakan air yang ada di dalam kelapa, bunga, beras dan umur si anak prempuan harus minimal 3-7 tahun"(jamaludin, 30 Oktober -2 November 2015)

Berdasarkan wawancara di atas dapat disimpulkan, bahwa tradisi tama lamong ini dapat dikatakan sebagai tradisi yang alurnya panjang dan memiliki tahap-tahap tertentu dalam pelaksanaannya. Tradisi tama lamong diiringi oleh sakeco yaitu membunyikan rebana ode dan rebana rea khususnya suku Sumbawa. Sedangkan untuk suku Buges di Daerah Sumbawa mengunakan gong genang tanpa mengunakan sakeco. Baik sakeco dan gong genang di iringi dengan basarakal. Sedangkan dikain putih si anak prempuan dioleskan warna kuning dibagian pinggirnya dan warna baju yang digunakan oleh si perempuan yaitu merah, hijau, biru, merah muda, hitam dan ungu.

Upacara ini dilaksanakan di atas tikar yang dinamakan "tipar lonjo atau tipar umpu". Dalam upacara ini harus tersedia perlengkapan-perlengkapan seperti : dila malam, loto kuneng, loto ketan, ketupat dan baju (lamong pene) sebanyak 7 buah dengan warna yang berbeda. Tradisi tersebut berlangsung sambil diiringi dengan sarakal dan ratib. Ketujuh baju yang brbeda warnanya tesebut secara bergantian dikenakan oleh orang yang berbeda, setiap pemasangan baju selalu ditaburi/lempari dengan beras kuning (loto kuning). Setelah baju dikenakan maka sandro (dukun) akan mengelilingi anak tersebut dengan dila malam sebanyak 7 kali samb il membacakan doa agar si anak tersebut kelak dapat menjadi anak yang solehah dan berguna bagi nusa dan bangsa.

Tradisi tama lamong ini merupakan salah satu tradisi masyarakat sumbawa yang dirangkaikan dengan upacara khitan (basunat). Tradisi tama lamong antara masyarakat sumbwa memiliki perbedaan denga suku Bugis seperti dalam hal musik pengiring dalam tradisi tama lamong tersebut.

\section{b. Fungsi Tradisi Tama Lamong}

Keberadaan tradisi tama lamong tidak terlepas dari faktor pendorong masyarakat melakukan tradisi tama lamong.Faktor pendorong tersebut adalah fungsi yang didapatkan oleh masyarakat ketika mereka melaksanakan tradisi tama lamong.Masyarakat Desa Rhee masihmempertahankan tradisi tama lamong, karena tradisi tama lamong memiliki fungsi yang cukup penting dalam kehidupan sosial mereka.

Berdasarkan teori fungsionalisme budaya yang dikemukakan oleh Malinowski dan Radcliffe Brown (Kaplan \& Manners, 2002) bahwa suatu budaya bertahan karena ternyata memiliki fungsi-fungsi tertentu bagi masyarakat yang bersangkutan.Tradisi tama lamong memang memiliki fungsi bagi kehidupan sosial masyarakat Desa Rhee, fungsi-fungsi tersebut saling berkaitan sehingga menyebabkan eksistensi tradisi tama lamong tetap terjaga.

Berdasarkan penjelasan diatas maka fungsi yang terdapat dalam tradisi tama lamong yaitu sebagai berikut:

1. Fungsi menjaga warisan budaya

Masyarakat Desa Rhee paham betul bahwa tradisi budaya adalah warisan yang diperoleh dari nenek moyang mereka. Mereka mengerti bahwa warisan budaya tersebut harus selalu terjaga keberadaanya. Dari beberapa responden penelitian yang kami wawancarai mereka menyatakan bahwa dalam melaksanakan tradisi tama lamong agar supaya anak cucu mereka dapat melestarikan tradisi tama lamong pula sehingga mereka juga mampu belajar untuk menjalin tali silaturahmi dalam keluarga.

Dalam Proses pewarisan suatu tradisi atau kebudayaan, keluarga dan masyarakat memiliki peran yang sangat vital. Di dalam keluarga seorang anak pertama kali belajar berbagai hal termasuk tradisi atau kebudayaan. Sedangkan lingkungan masyarakat berfungsi sebagai tempat dimana 
seorang anak melakukan proses sosialisasi maupun enkulturasi budaya.

Masyarakat Desa Rhee menganggap bahwa tradisi tama lamong adalah tradisi warisan yang memiliki nilai yang positif bagi mereka, sehingga menurut mereka tradisi ini sangat perlu dipertahankan, karena selain memiliki fungsi kesehatan juga memiliki fungsi sebagi pewarisan budaya, karena mereka tentu tidak menginginkan tradisi tama lamong ini hilang namun sebaliknya mereka menginginkan tradisi ini tetap dilestarikan oleh anak cucu mereka .

Berikut hasil wawancara bersama bapak M. Ali:

"selain untuk kesehatan anak tradisi tama lamong juga untuk melestarikan budaya. Kalau bukan kita yang memerhatikan warisan leluhur siapa lagi, karena inilah yang kita wariskan kepada anak cucu kita nanati." (Wawancara tanggal, 01 November 2015)

Dari pernyataan diatas dapat ditarik kesimpulan bahwa,keberadaan tradisi tama lamong dalam masyarakat Desa Rhee masih dilestarikan sampai sekarang,hal ini dibuktikan dengan masih banyaknya masyarakat yang melakukan tradisi tama lamong tersebut

2. Fungsi menjaga ikatan kekerabatan

Melalui tradisi tama lamong masyarakat mengundang para kerabat dan saudara untuk berkunjung dan bersilaturahmi.Melalui tradisi tama lamong pula banyak saudara yang bertemu.Khususnya kaum kerabat yang berada di wilayah tidak jauh dari Desa Rhee itu sendiri.Masyarakat Desa Rhee mengatakan bahwa tradisi tama lamong merupakan suatu acara yang membuat mereka bisa bertemu dengan para kerabat dan sanak saudara.Bentuk silaturahmi yang terjadi ketika tradisi tama lamong sebenarnya tidak jauh berbeda dengan bentuk silaturahmi ketika upacara perkawinan. Dimana perbedaan yaitu terletak pada musik yang digunaka, tradisi tama lamong mengunakan musik tradisional seperti ratib rabana ode, sedangkan dalam upacara perkawinan musikyang digunakan adalah sakeco.

Oleh sebab itu fungsi untuk menjaga ikatan kekerabatan tersebut menjadi penting untuk dilaksanakan oleh masyarakat Desa Rhee. Dikarenakan fungsi kekerabatan inilah yang menjadi fungsi yang paling melekatkan masyarakat pada tradisi tama lamong, Sehingga mereka selalu melaksanakan tradisitama lamong ini.

3. Fungsi menjaga ikatan solidaritas dan kerukunan warga

Melalui moment pelaksanaan tradisi tama lamong, masyarakat Desa Rhee memiliki ikatan kebersamaan satu sama lain. Baik itu ikatan solidaritas sesama warga desa Rhee maupun solidaritas dengan masyarakat desa lain. Ikatan solidaritas sesama warga terwujud dalam acara doa bersama pada malam hari ketika tradisi tama lamong berlangsung. Mereka memiliki tujuan berdoa yang samayaitu untuk keselamatan anak yang akan melaksanakan tradisi tersebut.
Pengumpulan uang atau barang secara bersama-sama yang dilebih dikenal dengan sebutan basiru membuat kebersamaan diantara mereka semakin erat. Apalagi pengumpulan uang atau barang tersebut di dasarkan atas kemampuan msaing-masing warga, sehingga pengenalan diantara mereka serta toleransi tumbuh dengan baik

Demikian hassil wawancara dari ibu Rada tanggal o3 November 2015:

"pengumpulan dana untuk iuran disesuaikan dengan kemampuan masing-masing orang. Kita tidak boleh menyamaratakan iuran. Karena tidak semua orang memiliki harta yang sama. Bukan untuk membedakan yang kaya dan miskin, hanya agar adil”

Disamping itu, pengumpulan uang atau barang secara bersama juga menimbulkan kepercayaan satu sama lain dalam mengelola dana tersebut. Unsur kebersamaan, toleransi dan kepercayaan yang terbangun untuk pelaksanaan tradisi tama lamong tersebut menimbulkan ikatan solidaritas dan kerukunan diantara mereka.Ikatan solidaritas antar warga terwujud dalam undangan untuk saling bersilaturahmi. Ketika masyarakat saling berkunjung dalam suatu acara, maka solidaritas dan kerukunan mereka akan selalu terjaga. Melalui kunjungan dan makan bersama, mereka dapat lebih mengenal satu sama lain.

\section{c. Makna tradisi Tama Lamong}

Makna adalah pertautan yang ada dalam unsurunsur bahasa itu sendiri, terutama pada tataran katakata. Makna sebagai penghubung bahasa dunia luar yang merupakan kesepakatan para pemiliknya sehingga terkadang sulit dimengerti oleh orang lain. Menurut Blumer dalam Soyomukti (2010:266) mengatakan bahwa makna adalah sebuah"produk sosial" yang artinya dengan melakukan interaksi dengan individu lainnya, sehingga kita dapat memperoleh sebuah makna dari simbol tertentu.

Menurut Pradopo dalam samsul Bahri (2013:58) mendefinisikan makna adalah tidak semata-mata merujuk pada arti bahasanya tetapi arti bahasa dari sudut suasana perasaan. Sedangkan Sudarna dalam samsul Bahri (2013:58) mengemukakan bahwa ada 3 (tiga) keberadaan makna yakni: (1) makna menjadi isi suatu bentuk kebahasaan, (2) makna menjadi isi dari kebahasaan dan (3) makna menjadi isi komunikasi yang mampu membuahkan informasi tertentu.

Berdasarkan kajian diatas makna yang terkandung dalam tradisi tama lamong dalam masyarakat Desa Rhee yaitu sebagai berikut:

1. Makna sosial

Sebagai mahluk sosial, dalam kehidupan sehari-hari kita senantiasa berinteraksi dengan orang lain. Manusia sebagai mahluk sosial yang memiliki gairah hidup bersama dengan manusia lainnya yang terpenting dapat mencapai tujuan hidupnya, akan tetapi merupakan sarana untuk pertumbuhan dan perkembangan kepribadiannya, (Amir hamzah dalam Jupri 2005:61).

Makna sosial bertujuan untuk menumbuh kembangkan rasa kebersamaan, rasa kesetia 
kawanan serta memupuk rasa persaudaraan sehingga, dengan demikian akan terhindar dari perselisihan.

Bertolak dari pendapat ahli diatas, maka makna sosial yang terkandung dalam pelaksanaan tradisi tama lamong sangatlah tinggi, karena hal tersebut dapat terlihat pada acara zikir dan do'a yang dilaksanakan setelah prosesi tama lamong. Dimana saudara, kerababat maupun tetangga dapat berkumpul, bercengkrama, bercanda gurau dan bersilaturrahmi, dari hal-hal tersebutlah jalinan keakraban dan ikatan persudaraaan akan terjalin. Berdasarkan hasil wawancara bersama bapak M Abdul salah satu informen (tanggal 30 Oktober 2015):

"Benar sekali, kalau kita perhatikan secara kasat mata, tradisi tama lamong ini tidak penting, tapi sebenarnya sarat akan makna yang tersembunyi, selain untuk keselamatan si anak kelak karena kita bersam-sama mendoa'akannya, juga kita dapat bertemu dengan saudara-saudara kita juga"

Hasil Wawancara diatas menyatakan bahwa selaiin untuk keselamatan, tradisi tama lamong juga memiliki makna persaudaraan, karena kehidupan manusia tidak bisa lepas dari hubungan sosial antara manusia yang satu dengan manusia yang lain, hal tersebut dapt dilihat dari cara mereka bergaul, bekerjasama sehingga akan menimbulkan makna dalam kehidupan mereka.

\section{Makna religi}

Menurut R.H.Codington (19440: 60) sebagaimana yang dikutif oleh Samsul Bahri (2013:60) menyatakan bahwa Religi adalah suatu emosi atau getaran jiwa yang timbul karena kekaguman manusia terhadap hal-hal dan gejalagejala tertentu yang luar biasa.

Sedangkan Rudolf Otto dalam Samsul Bahri (2013:60) menyatakan bahwa semua system religi, kepercayaan dan agama didunia berpusat pada suatu konsep tentang hal gaib yang dianggap maha dahsyat dan kramat oleh manusi, sehingga menimbulkan emosi atau getaran jiwa disebabkan sikap kagum dan terpesona.

Hal tersebut juga terlihat dalam masyarakat Desa Rhee yang mendukung tradisi tama lamong yang merupakan bentuk daur ulang untuk mencapai keselamatan.Tradisi tama lamong ini diyakini mengandung makna atau arti yang dapat memberikan manfaat serta faedah bagi kehidupan mereka yaitu suatu kebaikan, namun sebaliknya jika tradisi tama lamong ini tidak dilaksanakan biasanya si anak akan mendapatkan penyakit. masyarakat Desa Rhee sangat mendukung terlaksananya tradisi tama lamong di sebut.

Hal lain yang dapat dijelaskan bahwa makna religi yang terdapat dalam tradisi tama lamong ini tergambar melalui bacaan sholawat nabi yang di ucapkan oleh sandro (dukun), yang mana menurut kepercayaan masyarakat Desa Rhee yang mayoritas penduduknya beragama islam bahwa bacaan sholawat memiliki manfaat yang sangat luar biasa,seperti keselamatan,mendapatkan pahala dan do'a.

Makna shalawat kepada nabi Shallallahu 'alaihi wa sallam adalah meminta kepada Allah Ta'ala agar Dia memuji dan mengagungkan beliau Shallallahu 'alaihi wa sallam di dunia dan akhirat, di dunia dengan memuliakan peneyebutan (nama) beliau Shallallahu 'alaihi wa sallam, memenangkan agama dan mengokohkan syariat Islam yang beliau bawa. Dan di akhirat dengan melipat gandakan pahala kebaikan beliau Shallallahu 'alaihi wa sallam, memudahkan syafa'at beliau kepada umatnya dan menampakkan keutamaan beliau pada hari kiamat di hadapan seluruh makhluk. (diakses tanggal 25 November 2015)

Dari penjelasan diatas dapat ditarik kesimpulan bahwa tradisi tama lamong sangat sarat akan makna religi, sehingga hal inilah yang menyebabkan keberadaan tradisi tama lamong dalam masyarakat Desa Rhee masih tetap dipertahankan dan dilestarikan sampai sekarang.

\section{SIMPULAN DAN SARAN}

\section{Simpulan}

Dari hasil pembahasan yang telah dilakukan, maka dapat ditarik kesimpulan sebagai berikut:

a. Prosesi pelaksaan tradisi tama lamong adalah tradisi memasang atau mengenakan baju pada anak perempuan yang akan memasuki usia aqil baligh. Tama lamong dimasukkan sebagai pemberitahuan kepada anak bahwa ia akan memasuki usia remaja, sehingga dapat menyadari dirinya secara fisik maupun mental dalam menghadapi perubahan yang akan di alaminya. Beberapa kegiatan yang penting diketahui pada tradisi tama lamong adalah tradisi mandi air kembang dan tradisi pemakaian baju adat sumbawa. Dimana tahapan proses pelaksanaa tradisi tama lamong merupakan proses yang alurnya cukup panjang diantranya sebagai berikut: tahap pertama, persiapan perlengkapan tradisi tama lamong, dimana tahapan awal ini harus mempersiapakan semua perlengkapan yang digunakan tampa kurang satu pun, tahap kedua pelaksanaan tradisi tama lamong, dimana proses pelaksanaan tersebut bahwa tradisi tama lamong ini laksanakan pada malam hari atau pagi hari tergantung dari orang tua yang mempunyai hajatan. Dan tahap terahir atau tahap ketiga dari tradisi tama lamong adalah penutup acara, setelah pelaksanaan tama lamong dan basunat selesai, maka pada pada acara menutup ini dilakukan dengan membagi makanan yang sudah dibungkus olehpihak keluarga penyelenggara acara dan semua masyarakat yang datang mengahdiri acara tradisi tama lamong akan disuguhi makanan.

b. Fungsi tradisi tama lamong seperti: fungsi mnenjaga warisan budaya, menjaga ikatan kekerabatan an fungsi menjaga ikatan solidaritas dan kerukunan warga

c. makna tradisi tama lamong yaitu sebagai berikut: makna sosial dan makna religi.

\section{Saran}

Berdasarkan kesimpulan peneliti ini, maka ditemukan saran-saran sebagai berikut:

Diharapkan bagi aparat desa di daerah Sumbawa mulai dari tingkat dusun, desa, kecamatan sampai ke tingkat kabupaten agar lebih memperhatikan betapa pentingnya pelestarian budaya lokal khususnya masalah 
tradisi tama lamong adat sumbawa karena hal tersebut mencerminkan rasa kecintaan kita terhadap budaya sendiri secara turun temurun.

Diharapkan bagi tokoh adat, toko masyarakat dan masyarakat desa Rhee agar selalu mempertahankan melestarikan kebudayaan lokal, dalam hal ini mengenai tradisi tama lamong.

\section{DAFTAR RUJUKAN}

Koentjaraningrat.1998. kebudayaan metalitas pembangunan.jakarta: PT Gramedia. 2011.pengantar ilmu antropologi I.jakarta: Rineka Cipta.

2010.Prosedur penelitian suatu praktik. Jakarta: Rineka Cipta.

Arikunto, Suharsimi, 2010. Prosedur penelitian suatu pendekatan praktik. Jakarta: Rineka Cipta.

DEBDIKBUD.1995. Kamus Besar Bahasa Indonesia. Jakarta: Edisi kedua Balai Pustaka.

Depdikbud, NTB. 1988. Sejarah Daerah Nusa Tengara Barat. Mataram : Proyek Inventarisasi dan Dokumentasi Kebudayaan Daerah.

Elsentadt. 1986 "Revolusi dan Transformasi Masyarakat ", cet. 1. ( Jakarta : Rajawali)

Hadikusuma, Cet. 1, 1990, "Masyarakat dan Adat Budaya Lampun g”, Bandung, CV. Mandar Maju.

Hakim,2003. "Tradisi masyarakat Jawa”.Bandung.Mandar Maju

Iskandar,dkk. Seni Budaya Daerah Sumbawa. Sumbawa. Pendidikan Nasional Kabupaten Sumbawa.

Keraf, Gorys. 1989. "Tata Bahasa Indonesia. Flores” : Nusa Indah.

Koentjaraningrat. 2009. Pengantar ilmu antropologi.jakarta: Rineka Cipta.

Manca, Lalu. 1984. Sumbawa pada Masa Lalu (suatu tinjaun sejarah). Surabaya : Rinta

Mursal Esten. 1990, "Tradisi dan Modernisasi Dalam Sandiwara” Jogyakarta, intermasa.

Rahman, Jamal D. 2002. “Kaki Langit Sastra Pelajar”. Jakarta, Horison dan Yho Ford Foundation.

Rauf, Yusuf. 2001. "Seni Budaya Daerah. Sumbawa" : Dinas Pendidikan Nasional.

Ryanto, Yatim.2010, metode penelitian. Jakarta, :PT.Raja Grapindo.

Saebani, Beni Ahmad, 2009.Metode penelitian.Bandung; Pustaka Setia.

Shil. 1981,"sejrah tradisi masyarakat”, Jakarta, Bulan Bintang.

Sidi Gasallba . 1976, "Masyarakat Islam, Pengamat Sosiologi dan Sosiografi”, Jakarta, Bulan Bintang.

Sugiyono, 2012.Memahami penelitian kualitataif.Bandung; CV Alfabet.

Sugiyono. 2012. Metode penelitian kualitatif $R \& D$. Bandung: Alfabeta.

Thomas Wiyasa Bratawidjadja, 1996, "Upacara Tradisional Masyarakat Jawa”, Jakarta, Pustaka Sinar Harapan

Yanis Maladi, 2011."tradisi sejarah masyarakat Indonesia”.jakarta.pustaka sinar harapan

Netti Liskayanti, "Upacara Adat Besunat"

\section{b. Internet}

Dimas, "Tama Lamong”, http://dimascx2.blogspot.com/2012/03/tama-lamong.html, diakses, $26 \quad$ Mei 2015http://karyailmiah.um.ac.id/index.php/sejarah/article/view/7 94, diakses, 26 Mei 2015

http://nettiliskayanti.blogspot.com/2012/12/upacaraadat-basunat.html, diakses, 26 Mei 2015

Khitan Wanita, http://www.eramuslim.com/ustadzmenjawab/wajibkah-wanita-dikhitansunat.htm, diakses, 26 Mei 2015

M Ganif Haruman,"pengertian kebudayaan"http://sobatbaru. Blogspot. Com/2008/04/o9 pengertian-kebudayaan. Htmlhttp://muhamadganifharuman.blogsop.co m/2012/o3/pengertian-kebudayaan-dan-7unsur.html 